\title{
Methodological Basics of Blended Learning in Teaching English for Academic Purposes to Engineering Students
}

\author{
Dmitry L. Matukhin ${ }^{1}$, Gavriil A. Nizkodubov ${ }^{1}$, Vadim Y. Zyubanov ${ }^{1}$, Yury R. Khasanshin ${ }^{1}$ \& Aleksandr V. \\ Obskov $^{1}$ \\ ${ }^{1}$ Tomsk Polytechnic University, Russian Federation \\ Correspondence: Dmitry L. Matukhin, Lenin Avenue, 30, Tomsk, Tomsk region, Russian Federation. E-mail: \\ mdlbuddy@mail.ru
}

Received: June 12, 2014 Accepted: July 30, 2014 Online Published: September 28, 2014

doi:10.5539/ass.v10n20p97 URL: http://dx.doi.org/10.5539/ass.v10n20p97

\begin{abstract}
This article dwells on the problem of electronic and blended learning systems implementation in the English for Academic Purposes (EAP) teaching process at the engineering universities. The objective of these systems implementation is to optimize the process of communicative competence development for the professionally-oriented communication. The relevance of the problem is justified by several factors. Firstly, Foreign Language (FL) is not a major course, and then the amount of contact hours allocated to its mastering seems to be extremely insufficient. Therefore, the purpose of developing the professionally-oriented communicative competence at a level sufficient to conduct successful foreign language communication in the professional field seems to be rather elusive. Secondly, graduates' requirements for the foreign language proficiency are quite high. Future engineers need Foreign Language both as a means of intercultural communication and as a source of specialized information. In this paper e-learning and blended learning have been defined, the components of the blended learning system such as tools, modes, methods, objectives and content of learning process which affect the structure of blended learning model have been stated. Moreover, the principles of EAP teaching for the engineering students within the blended learning system on the basis of an electronic educational Resource EAP ToolKit have been described in order to affect strongly the nature and effectiveness of the methodological system.
\end{abstract}

Keywords: blended learning, e-learning, engineering students, FL teaching, English for academic purposes, EAP Toolkit

\section{Introduction}

The system of higher education today is undergoing significant changes, in particular, there is a transition from the traditional five-year education system, the outcome of which becomes a diploma and qualification of "engineer", to double degree system, which includes undergraduate and graduate courses, qualification of "engineer" vanishes from modern graduate diplomas. However, in today's universities, as before, remains engineering degree training. Nevertheless, the notion of an "engineer" and the requirements for graduates of engineering universities should be clarified.

Interpretation of this notion may be different. Kapustin Yu. I. (2010) and Zhelnova E. V. (2010) give the following definition: "The word "engineer" comes from the Latin "ingenium"-"ingenious invention" and essentially means the creator of new life benefits and skills, new tools and new weapons for war and hunting, new devices and facilities, means of transport and ways of entertainment. In a more generalized sense it is the creator of new products and services". There are different, narrower interpretations of the notion (Mokhova, 2011). To be sure, the engineer must be fully developed personality, well-versed in the various fields of knowledge and not focused exclusively on his field of activity. Not coincidentally, many professional organizations today are interested not just in good specialists and conscientious executors but creative thinking staff capable of converting innovations in planned activities with extraordinary problems solving skills (Matukhin, 2014).

High FL proficiency is an integral feature of an engineer-creator because it provides more opportunities for both professional search for relevant information and scientific self-expression, communication and cooperation with like-minded colleagues from different countries. 
Education and learning FL in general and EAP in particular in an engineering university are a complicated task, both for instructors and students. As this course is not a major, the amount of contact hours devoted to it is insufficient; therefore, the purpose of professionally-oriented communicative competence at a level sufficient to conduct successful foreign language communication in the professional field seems elusive (Siemens, 2009).

At the same time, students' requirements for foreign language proficiency are quite high. Future engineers need foreign language both as a means of intercultural communication and as a source of specialized information (Matukhin, 2013).

Therefore, it is necessary to apply the most advanced tools and methods of the educational process that will allow using, in the most efficient way available to the instructor and student, capabilities and resources. The latter include electronic textbooks, manuals, e-learning courses and systems, online training, webinars, e-mail and Internet conference, as well as other facilities, which in the whole constitute the major means for implementing e-learning technologies (Valiathan, 2002).

This paper deals with the theoretical bases of electronic and blended learning in teaching EAP and the development of professionally-oriented FL communicative competence for engineering students.

\section{Materials and Methods}

The research is based on the scientific papers of domestic and foreign scholars in such areas as general theory of professional education, teaching principles and methods of learning (Jochems, 2004); andragogy, theory and methods of teaching foreign languages (Siemens, 2009), theory and practice of integrating information and communication technologies in the educational process (Desmet \& Strobbe, 2011), theory and practice of blended learning (Next Generation Learning Challenges, 2008). Corpus of methods includes general scientific and specific teaching methods: descriptive and comparative methods, method of specification, analysis and synthesis, classification as well as comparative, modeling and systemic-functional methods.

\section{Results}

Methodological basics of organizing EAP teaching a as part of e-learning include the principles of educational process, modes of study, tools and techniques. All these components are discussed thereunder. It is reasonable to define the notions used in the article.

E-learning (e-learning)-defined by UNESCO specialists-is learning through the Internet and multimedia resources. This term implies intensive application of computer, multimedia, Internet resources and remote communication systems. In the course of e-learning implementation, many students work independently with electronic materials (textbooks, courses, training systems), while consulting with the instructor remotely via the Internet.

In the same way the Internet communities are created (e.g. a community based on the electronic learning environment "Moodle". The purpose of the latter is to provide students and academic staff with common environment in which they can in handy circumstances for both parties-time, place, etc.-carry out the process of teaching and learning, conduct online tutorials, receive and evaluate writing assignments fulfilled by students, keep records of student's work, etc. Contact hours, in this case, set aside for discussing with students professionally pressing problems (in the foreign language).

The benefits of such training refer to the possibility of instant assignment delivery, as well as the return of the evaluated papers with instructor's recommendations and comments. Thus, e-learning is closely associated with distance learning, may be associated with correspondence learning and is often understood as learning through the Internet. It is often applied by the companies for corporate training and staff development. This mode of study has already been legalized by amendments to the Federal Law "About Education" (Federal Law of the Russian Federation dated February 28, 2012 № 11-FZ "About Amendments to the Russian Federation Law "About Education" regarding the application of e-learning , distance learning technologies").

In accordance with this law, e-learning is defined as "organization of the educational process based on information contained in databases and used in educational programs, information technologies that provide its processing, hardware, as well as information and telecommunications networks, ensuring the transmission of information via communication lines, interaction of participants in the educational process".

However, teaching EAP is associated with a number of features that reduce the effectiveness of e-learning in its pure form. In particular, the purpose of teaching EAP for engineering students is to develop professionally-oriented communicative competence, which is almost unattainable due to extremely insufficient number of contact hours and implementing just e-learning technology. 
This goal seems achievable provided that professionally-oriented communication is effectively organized in class. In this case, it is reasonable to use blended learning technology.

The latter allows us to combine capabilities of e-learning and face-to-face communication with an instructor and classmates. On the one hand, leading role refers to self-study using electronic resources, on the other hand, contact hours are diverted to developing communicative competence and not to checking out the homework.

There are many approaches to the definition of blended learning. Most of them agree on the combination of face-to-face and distance activities using electronic information and communication means.

Thus, blended learning is defined as integration of strict formal learning tools-working in class, studying of theoretical background-with informal, for example, discussion via e-mail and Internet conferences, combination of different modes of content delivery, training that merges various types of learning activities (including in-class learning, e-learning and learning in the workplace), combination of "face-to-face" and "on-line" communication, supervised and independent choosing the ways to achieve their goals and objectives (Rossett \& Douglis, 2009).

Following Donald Clark (2009) in his article "Blended Learning", we define blended learning as implementing, in one way or another, electronic and in-class learning.

Thereby, blended learning is a training method that combines the benefits of in-class learning and e-learning. Autonomous students' work over electronic materials on-line is "blended" with face-to-face work in the group with an instructor. Such organization of the educational process is characterized by the following benefits:

1) Blended learning allows students to acquire new knowledge independently, using electronic resources; meanwhile, actively practice new skills in class through intensive communication with an instructor and other course participants (classmates). This feature is highly relevant for the development of professionally-oriented communicative competence for engineering students.

2) Blended learning allows balancing basic and background knowledge of all students in the group (ultimately bring the group to the desired level) due to the self-study of theoretical materials offered by an instructor and implementation of the proposed additional exercises. Thus, individual student's approach is realized within the heterogeneous group in terms of FL proficiency.

3) Blended learning allows diversifying the modes of learning organization (e.g. face-to-face activities-in-class learning, tutoring by email, blogging, chatting, etc.).

4) Blended learning stimulates the development of self-learning skills and data retrieval (the need for mastering the material self-confidently promotes responsible attitude to learning, time management, personal activity in search for information).

5) As announced, blended learning accounts for individual features of perceiving information (students have individual characteristics of perceiving and processing information).

There are various models of blended learning organization. Most researchers identify two approaches to the organization of blended learning.

Proponents of the first approach understand blended learning as a mode of educational process, which is based on the distance learning course that integrates some active learning methods implemented in class activities with students. Theoretical material is mastered through e-learning course, which involves student's self-study but in class skills are practiced and reinforced based on the game like methods, active discussions, search for solutions, etc. (Thorne, 2004; Bersin, 2004).

According to the second approach, blended learning is implemented as a model based on distributed information and educational resources for in-class learning using elements of asynchronous and synchronous distance learning (Valiathan, 2010). When organizing foreign language learning in an engineering university, it seems appropriate to base on the second model of blended learning, where e-learning methods are integrated into in-class learning. Contact hours are diverted to an active FL discussion of the issues related to the future professional activities. Preparing for this discussion is carried out by means of blended learning.

The main components of the blended learning model in relation to the course of "English for Academic Purposes" are as follows:

- content component, assuming natural combination of theoretical knowledge in the course of study and personally meaningful tasks that promote student as a specialist in a particular area;

- instrumental component that involves distance (electronic) learning technologies in the educational process, management system and assessment, including criteria and indicators of students' outcomes. 
These components, borrowed from Kapustin Yu. I. (2010), whose research interests involve programming learning, has been processed in accordance with the needs of foreign language as a subject. These aspects determine organizational modes of joint activity of the instructor and the student.

When organizing educational process within the blended learning it is necessary to combine group and individual, real and virtual modes of study, in addition to traditional modes of teaching foreign language. In relation to the course of English for Academic Purposes in an engineering university, the proposed blended learning model involves rather focused, intense and controlled students' self-study who performs tasks assigned by the instructor using e-learning tools and practices their foreign language skills in professionally-oriented communication in the classroom. Following Riznar (2010), we specify that students' self-study in the course of EAP teaching includes as follows:

- performing vocabulary and grammar tasks that traditionally occupy a lot of time in class. Assessment of such tasks can be carried out through the electronic learning environment;

- performing writing tasks that imply various modes of assessment;

- performing tasks aimed at the developing listening and reading skills;

- writing various types of essays and reports;

- reviewing, project activities and their subsequent presenting in class.

When organizing educational process based on the blended learning model, content, methods and modes of study are selected on the basis of their compliance with the learning objectives and the effectiveness of the learning process. They are presented in the form of teaching materials, including electronic textbooks, workbooks both hard copy and electronic version, test booklets, self-study manuals, audio, video, $\mathrm{CD}$, etc. As regards selection of teaching material application of a textbook in its traditional mode has not lost its relevance but students should be able to choose the most convenient mode of introducing teaching material (Global Understanding, 2011).

There is no doubt that all the selected tools, modes and methods, objectives and content of learning process affect the structure of blended learning model, in other words, combination of the selected components directly affect the nature and effectiveness of the methodological system.

It is well known that teaching FL is subject to various general didactic and methodological principles. The success and effectiveness of teaching English for Academic Purposes in an engineering university based on electronic and blended learning is provided in accordance with the following principles:

1) Principle of consciousness. Implementation of blended learning in EAP teaching for engineering students is based on conscious attitude to FL learning and to the modes of study.

2) The principle of diligence is inseparable from electronic learning or blended learning, since the mode of organization involves a high level of students' autonomy.

3) The principle of "learning endurance" is ensured by opportunities offered by blended learning-student can return to any step in the e-course to work out once again the most challenging tasks.

4) The principle of account for students' individual features which is most fully realized within the computer courses. It's provided by individual ways of learning activities, choice of the individual rate, support tools to individual learning and adaptation of the learning system to the individual features of a student.

5) The principle of commitment to the specific students is one of the key as in the course of professional training it's necessary to take into account individual psychological features of students, as well as the scope of their professional activities.

6) The principle of stimulating and motivating students toward the positive attitude to learning which involves creation of learning environment resulting in the emergence and maintenance of learning motivation (Blended learning, 2009).

Blended learning technology described there in before could be implemented in the EAP teaching for engineering students (undergraduates, graduates) and academic staff by means of such an electronic educational Resource as EAP ToolKit which provides methodological support throughout the period of teaching EAP (Electronic educational Resources EAP Toolkit, 2013).

The Resource contains seven sections including 114 topics, each of which is composed of a certain number of tasks designed for self-study and in-class activities. EAP ToolKit includes the following sections:

1) The ability of learning (Learning skills). 
2) Academic Writing (Academic writing).

3) Vocabulary for Academic Purposes (Vocabulary for academic purposes).

4) Grammar for Academic Purposes (Grammar for academic purposes).

5) Reading and critical thinking (Reading and Critical thinking).

6) Listening and note-taking (Listening and Note-taking).

7) Ability to communicate (Communication skills).

Common to all the sections are such categories as structure, design, number and volume of tasks, worksheets, focus on the development of analytical thinking and autonomous learning, didactic potential of additional resources. Then follows a processing analysis of the Resource by the sections, including its potential to be integrated into the syllabus (Slesarenko \& Prokhorets, 2014).

Design and navigation

All the Resource assignments are designed in an interactive manner and provided with media support, accompanied by feedback with suggested answers, examples and explanations. EAP Toolkit elements, in general, allow us to organize step-wise mastering the materials, which are divided into didactic units. This Resource possesses simple, functional, well-balanced and intuitive interface that allows us to consider good prospects and wide scope of EAP ToolKit as a self-study means for EAP learning.

Number and volume of tasks

Each topic offers 2 to 4 tasks. On average, mastering one topic takes 20 to 60 minutes of in-class activity based on the detailed discussion of the presented material.

Didactic worksheets

Some sections include worksheets (e.g. Learning Skills, Communication skills), didactic handouts (e.g. Reading and Critical Thinking) which can be printed for further analytical work. Reading and Critical Thinking section contains texts for performing online tasks.

Development of analytical thinking and autonomous learning

Almost all the sections are provided with the tasks for the development and improvement of analytical thinking skills and autonomous learning.

Didactic potential of additional resources

The Resource is provided with additional reference materials (Dictionary, Glossary, Weblinks, References) and explanatory notes (Show Help). The option of looking up the glossary should be highlighted, which allows students to organize terminology. In addition, variety of dictionaries is a functional tool for mastering unfamiliar vocabulary. Feedback and explanatory notes are also well represented, so students aren't expected to have objective difficulties in their interpretation.

\section{Discussion}

Electronic educational Resources EAP ToolKit possesses great didactic potential; it is distinguished by ease of navigation and interface, splendid design, a variety of tasks, extensive vocabulary and a feedback option. In our view, the Resource can be used as a means of EAP teaching for engineering students through the implementation of blended learning technologies. Moreover, EAP Toolkit as a part of the blended learning technology allows us to create units, modules and successfully integrate them into the existing syllabus. However, the main obstacles, when dealing with EAP Toolkit, refer to inadequate students' foreign language skills to perform certain tasks associated with listening, grammar as well as difficulties of the task translation due to abundance of new terminology.

\section{Conclusion}

To sum up, undergraduates and graduates are psychologically considered as adults, consciously treating their professional choice and future career. They also possess some features peculiar to adult learners, namely: practical orientation associated with awareness of professional prospects, the need for learning justification that is closely associated with the motivation and the need for autonomy that is inherent in this age group. These qualities of undergraduate and graduate students not only should be used in EAP teaching but also to be maintained and developed through the appropriate modes of study. It should be emphasized that in the case of competent blended learning organization based on the given didactic and methodological principles, limited combination of face-to-face and electronic FL learning in accordance with the adequate set of means and 
methods, development of professionally-oriented communicative competence could be more efficient under the conditions provided by the engineering universities.

\section{References}

Bersin, J. (2004). The blended learning book: Best practices, proven methodologies and lessons learned (p. 330). San Francisco: Pfeiffer.

Blended Learning. (2014). GrayHarriman.com, E-Learning Resources. Retrieved from http://www.grayharriman. com/blendedlearning.htm\#5

Clark, D. (2009). Blended learning. CEO Epic Group plc., 44.

Desmet, P., \& Strobbe, J. (2011). ELT and Blended Language Learning: From theory to practice. Retrieved from http://www.britishcouncil.org/ru

E-Learning Resources. (2009). Retrieved from http://www.grayharriman.com/blended learning.htm\#5

Electronic educational Resources EAP Toolkit. (2013). Retrieved from http://www.elanguages.ac.uk/tomsk

Global Understanding. (2011). Retrieved from http://www.ecu.edu/cs-acad/globalinitiatives/course

Jochems, W. (2004). Integrated e-Learning: Implications for pedagogy, technology and organization (p. 212). London, Routledge Falmer.

Kapustin, Y. I. (2010). Pedagogical and organizational conditions for effective combination of face-to-face and distance learning technologies. $\mathrm{PhD}$ thesis, Moscow State University.

Matukhin, D. L. (2013). Competence approach as a basis for foreign language learning in an engineering university (p. 187). Tbilisi: Publishing House "UNIVERSAL".

Matukhin, D. L., \& Evseeva, A. M. (2014). Further professional training as a constituent part of continuing vocational education. Proceedings of the 2nd International Conference in Humanities, Social Sciences and Global Business Management, June 21-22, IERI, London, UK.

Mokhova, M. N. (2011). Active methods of blended learning in the system of extended vocational education. $\mathrm{PhD}$ thesis, Moscow State University.

Next Generation Learning Challenges. (2014). Underlying Premises: Blended Learning. Retrieved from http://www.net.educause.edu/ir/library/pdf/NGLC002.pdf

Riznar, I. (2010). Blended learning. Retrieved from http://www.ibs.si/docs/KombiniranoucenjeJezikov.pdf

Rossett, A., \& Douglis, F. (2009). Strategies for Building Blended Learning. Retrieved from http://www.essential learning.net/news/Strategies\%20for\%20Building\%20Blended\%20Learning.pdf

Siemens, G. (2009). Connectivism A Learning Theory for the Digital Age. Elearnspace. Retrieved from http://wvw.elearnspace.org/Articles/connectivism.htm

Slesarenko, I. V., \& Prokhorets, E. K. (2014). Testing an electronic resource EAP ToolKit in TPU (2013/14) (p. 17). Analytical note, Tomsk: TPU.

The 2004 e-readiness rankings. (2004). London, the Economist Intelligence Unit Limited and IBM Corporation, 30.

The Common European Framework in its political and educational context. (n. d.). Retrieved from http://www.coe.int/t/DG4/Portfolio/documents/0521803136txt.pdf

Thorne, K. (2004). Blended learning: How to integrate online and traditional learning (p. 148). London, Kogan Page.

Valiathan, P. (2002). Blended Learning Models. Retrieved from http://www.learningcircuits.org/2002/aug2002 /valiathan.html

Zhelnova, E. V. (2010). Missed Steps, Training \& Development. Retrieved from http://www.obs.ru/interest/publ/ thread $=57$

\section{Copyrights}

Copyright for this article is retained by the author(s), with first publication rights granted to the journal.

This is an open-access article distributed under the terms and conditions of the Creative Commons Attribution license (http://creativecommons.org/licenses/by/3.0/). 